\title{
Facilitation of Social Support for Expectant Students in South Africa: A Concept Analysis
}

\author{
Sogo F Matlala ${ }^{1}$ \\ ${ }^{1}$ Department of Public Health, University of Limpopo, South Africa \\ Correspondence: Sogo F Matlala, Department of Public Health, University of Limpopo, Private Bag X1106, \\ Sovenga, 0727, South Africa. Tel: 015-268-3404. E-mail: France.Matlala@ul.ac.za
}

Received: March 29, 2018 Accepted: May 1, 2018 Online Published: May 25, 2018

doi:10.5539/gjhs.v10n6p173 URL: https://doi.org/10.5539/gjhs.v10n6p173

\begin{abstract}
The objective was to analyse 'facilitation of social support' to contribute to its understanding. This followed data analysis of a qualitative study on experiences of expectant students, their close relatives and educators on facilitation of social support to expectant students. Dictionary and subject definitions were used to make it clear. A model case was constructed to illustrate its use. Antecedents and consequences were identified. Its implementation may end in regular antenatal care attendance where professional nurses provide personalized care by communicating with expectant students, their close relatives and educators to enable their retention in school and ultimately giving birth to healthy babies.
\end{abstract}

Keywords: antenatal care, facilitation, expectant students, social support, school retention

\section{Introduction}

Pregnancy among students, also known as learner pregnancy, is a health, educational and social challenge in South Africa. This is because expectant students are not experienced to handle pregnancy and the consequent child raising (Bhana \& Mcambi, 2013). Accidental learner pregnancy has also been found to disturb learning for expectant students (Miriri, Ramathuba, \& Mangena-Netshikweta, 2014; Matlala, 2016; Skobi \& Makofane, 2017). Others got humiliation and negative judgement from their mates, close relatives, educators and professional nurses, while some got support (van Zyl, van der Merwe, \& Chigeza, 2015; Skobi \& Makofane, 2017). Learner pregnancy happens commonly outside of marriage, hence it is disapproved as most people in South Africa regard marriage as an institution in which pregnancy has to happen (Baxter \& Moodley, 2015; Baloyi, 2016).

Some of the expectant students are excluded from schools while others get expelled if their pregnancies are showing (Mutshaeni, Malovhele, Lebese, \& Mashau, 2015; Moletsane, 2011). Others drop out of school on their own due to anxiety and sometimes due to pressure from some educators and community members (Mnguni, 2014). Consequently, most hide their conditions (Shefer, Bhana, \& Morrel, 2013). Some of those who survive expulsion, haphazardly attend antenatal care (ANC) due to inadequate support from educators and close relatives to deal with the demands of being a student and the duty to go for ANC (Matlala, 2015). Others give birth while at school due to their failure to recognise signs of labour or labour taking place before the expected date of delivery as teens have a greater risk of premature labour (Baxter \& Moodley, 2015).

A study on providing social support to expectant leaners reveals a need for facilitation of social support to keep expectant students in schools (Matlala, 2016). Expectant students are allowable by government policy to remain in school to get an education. Studies (Matlala, 2015; Mutshaeni, Malovhele, Lebese, \& Mashau, 2015; Matlala, Nolte, \& Temane 2014), however, show that expectant students are not receiving satisfactory social support from their educators and close relatives to remain in school. There is thus a need for professional nurses and educators to facilitate social support for expectant students to enable them to remain in school. Currently little is known about the meaning of 'facilitation of social support for expectant students' in South African schools.

\subsection{Aim of the Study}

The aim was to conduct a concept analysis of 'facilitation of social support' to improve its understanding and use among members of the helping profession, who are educators, professional nurses and social workers (Williams, 2016; Hrbackova \& Suchankova, 2016; Škvorc \& Bjelajac, 2016; Moxley \& Feen, 2017). A concept analysis is necessary to provide clarity and create a common understanding on concepts that are used frequently while having 
different meanings (Lin, Rong \& Lee, 2013; Schenck \& Louw, 2008).

\section{Method}

\subsection{Field Work}

The researcher conducted a qualitative and theory-generating study to explore how educators, expectant students and their close relatives facilitate social support to expectant students in South Africa (reported in another paper). The findings were discussed within relevant literature as suggested by Streubert and Carpenter (2011). By means of derivation and synthesis methods recommended by Walker and Avant (2011), the concept 'facilitation of social support' emerged. This concept is made of 'facilitation' and 'social support' as two concepts which are used frequently in education, nursing and social work. It is therefore important to understand its meaning when applied to expectant students who attend schools in South Africa.

\subsection{Concept Analysis Process}

A concept analysis method of Chinn and Kramer (2011) was used where 'facilitation of social support' was identified as the key concept. The researcher defined it by means of dictionary and subject definitions methods recommended by Chin and Kramer (2011) and Walker and Avant (2011) to make the concept clear. A model case was formed to show the practical use of the concept. Its antecedents and consequences were also identified and discussed.

A search of education, nursing and social work literature was done to identify and define characteristics related to facilitation of social support. Dictionaries were also used to define linked concepts, and to look for its synonyms and antonyms. The concepts 'facilitation' and 'social support' were defined individually then synthesized to a core meaning of 'facilitation of social support' to clearly understand it and its use. As recommended by Chinn and Kramer (2011) and Walker and Avant (2011), the researcher incorporated definitions from education, nursing, social work and related fields of study to expand and deepen those definitions.

\section{Results}

\subsection{Dictionary Meaning of the Concept 'Facilitation'}

Facilitation is a noun derived from the verb 'facilitate' which talks about speeding up an action. It is linked to enhancement, derived from enhancing, meaning to intensify the significance, worth or amount of something (Oxford South African Concise Dictionary, 2006). Facilitation is furthermore derived from the verb facilitate, which talks about making an activity or procedure easier (Oxford Dictionary of English, 2006). According to Collins Dictionary of English (2011), facilitation is a process of increasing and making an action easier. It further explains facilitate as to support the progress of or to make the process easier. Expedite, ease, forward, further, promote, help, assist the progress of, oil the wheels, pave the way for, make easy, speed up and smooth the path of are the synonyms of the verb facilitate (Collins English Thesaurus, 2013). The antonyms of facilitate are delay, impede, thwart, frustrate, restrain, hamper, hinder, prevent and obstruct.

Facilitation, consequently, means enabling a procedure to take place easily by taking away obstructions and delays.

\subsection{Subject Meaning of the Concept Facilitation}

To increase comprehension of facilitation further than its dictionary connotation as guided by Chinn and Kramer (2011) and Walker and Avant (2011), the researcher reviewed the literature to comprehend the use of the concept 'facilitation' in many perspectives. Schenck and Lou (2008) and Petrova, Dale, Munday, Koisten, Agarwal and Lall (2010) refer to facilitation as a method of supporting people or groups to succeed. They regard facilitation as driven by a facilitator who is a change agent supporting advancement. Rycroft-Malone, Seers, Chandler, Hawkes, Grichton, Allen, Bullock and Strunin (2013) talk about facilitation as enabling and making things easier in their study on the meaning of facilitation in the implemention of research results. These authors, too, regard facilitation as an activity steered by a facilitator.

Facilitation is therefore defined as an empowering activity steered by a facilitator who makes it easier for others to be successful.

\subsection{Defining Attributes of Facilitation, Social Support and Facilitation of Social Support}

Defining attributes are characteristics commonly related to concepts and assist researchers to gain a deeper understanding of those concepts (Walker, \& Avant, 2011). They are identified through analysis of the different uses of concepts and may be categorized into essential and related attributes (see Table 1). 


\subsection{Summary of the Meaning of Facilitation}

Facilitation means an empowering activity of promoting, easing actions, furthering and enabling through oiling the wheels and paving the way to hasten activities by giving support and proposing suggestions to overcome obstacles.

Table 1. Defining attributes of the concepts 'facilitation', 'social support' and 'facilitation of social support'

\begin{tabular}{|c|c|}
\hline \multicolumn{2}{|c|}{ Defining Attributes of 'Facilitation' } \\
\hline Essential Attributes & Related Attributes \\
\hline Easing & - To make actions or processes easy or easier \\
\hline Empowering & - To give power or authority to take control \\
\hline Enabling & - $\quad$ To make things possible or easy \\
\hline \multicolumn{2}{|c|}{ Defining Attributes of 'Social Support' } \\
\hline Essential Attribute & Related Attributes \\
\hline Encouraging & - $\quad$ To give confidence to overcome barriers \\
\hline Helping & - To render assistance \\
\hline Communicating & - To share and exchange information \\
\hline Networking & - To enrich relationships in order to enhance the quality of your work \\
\hline Esteem & - To be seen as someone worthy of respect \\
\hline Competence & - To have the necessary skills, information, help and other resources needed to succeed \\
\hline \multicolumn{2}{|c|}{ Defining Attributes of 'Facilitation of Social Support' } \\
\hline Essential Attribute & Related Attributes \\
\hline Empowering & - $\quad$ To give power or authority to take control \\
\hline Encouraging & - To give the confidence to overcome barriers \\
\hline Helping & - To render assistance \\
\hline Enabling & - $\quad$ To make activities possible or easy \\
\hline Networking & - To enrich relationships in order to enhance the quality of your work \\
\hline Communicating & - To share and exchange information with others \\
\hline Competence & - To have correct information, skills, help and other resources needed to succeed \\
\hline Easing & - To make an action or process easier \\
\hline
\end{tabular}

\subsection{Dictionary Meaning of 'Social Support'}

According to Oxford Advanced Learner's Dictionary (2010), support is a noun and a verb. Support, as a noun, refers to help in the form of money or encouragement that one can give to people one favours and wishing them to be successful. The concept also refers to sympathy and help that one gives to people facing difficult or unhappy situations. To hold in place is an additional meaning of support and means keeping something firmly in place thereby stopping it from dropping. Support furthermore refers to a strapping used to hold wounded or frail organ firmly in place. Support, as proof, refers to evidence showing something as being factual. Support, as a noun, denotes technical service a company provides to clients using its products such as medical equipment and computers. Supportive is an adjective of support and refers to helping and encouraging a person (Oxford Advanced Learner's Dictionary, 2010). Support is an adjective that can be used in 'supportive of treatment' to refer to something intended to reinforce a patient's defence to overcome diseases (Oxford Dictionary of Nursing, 2008).

Support, as a verb, means to help or encourage people by showing that one agrees with them. It also refers to giving help or being prepared to assist others. Support further means giving money to help or encourage people to be successful. Other dictionary meanings of support include to hold something in place, to stop something from dropping and to attest that something is correct.

The concept 'social' is an adjective talking about having to do with society and its organizations, and about people 
needing the company of others or living in organized communities (Oxford South African Concise Dictionary, 2006).

\subsection{Subject Meaning of Social Support}

The concept social support talks about communication to ease anxiety and have an increased feeling of being in control of your life (Mattson \& Hall, 2011). It also refers to a network of relatives, neighbours, mates and members of the community who are prepared to offer physical, psychological and monetary help. Social support is relationships involving communicative methods which increase esteem, coping, belonging and competence through sharing of physical or psychological resources. Duman and Kocak (2013) outline social support as monetary or spiritual help given by close relatives and mates to a person in distress.

Mattson and Hall (2011) indicate forms of social support as information support, emotional support, tangible support, network support and esteem support. A text message or a get-well-soon card are expressions of emotional support which when sent to patients, uplift their moods. Esteem support, which Heaney and Israel (2008) refer to as appraisal support, is about encouraging others to act by convincing them of their ability to deal with challenges. Esteem support helps to increase self-esteem or confidence in the capacity to manage challenges or do required tasks. Network support is a form of communication to remind people that they belong. It confirms their belonging to a network and reminds them of availability of support from the network. In their study on community service by student educators in South Africa, Kwatubana and Mtimkulu (2016) show the significance of network support to students. Information support is communication to provide supportive information. Someone recently diagnosed with a life-threatening health condition needs information to comprehend the condition and treatment possibilities (Mattson \& Hall, 2011).

Tangible support is physical aid like materials and activities given to people going through challenges (Mattson \& Hall, 2011). It includes accompanying an expectant student to the nearest healthcare facility to receive care. Monetary support is an illustration of tangible support given by Kanku and Mash (2010) when reporting that some teenagers became pregnant to gain monetary support from boyfriends and from the state by means of child support payments while Kheswa and Hoho (2017) found that some female university students had multiple sexual partners to gain monetary support.

Roos, Faure, Lochner, Vythilingum and Stein (2013) found that a high level of psychological symptoms amongst expectant women is linked with inadequate social support for the duration of pregnancy. Studies by Parker (2011) and Yeboah (2012) show that in some communities in Africa, relatives offer social support to expectant and breastfeeding women as a tradition. The authors further show that social support is a necessity whose deficiency causes anxiety. Social support helps expectant teenagers to cope with their pregnancies (Motjebele, 2009). Manikkam and Burns (2012) and Kim, Connolly and Tamim (2014) also reveal that during pregnancy, insufficient social support may result in depression. Duman and Kocak (2013) and Maharlouei (2016) support the observation that social support decreases pregnancy-related anxiety and stress while Masala-Chokwe and Ramukumba (2017) indicate that first-time mothers who still feel inadequate need social support as they learn to care for their babies.

The importance of social support in ensuring adherence to treatment is shown by Kheswa (2017) and Mona (2014) in their studies on adherence to antiretroviral therapy in South Africa. Mona (2014) further recommends social support to be offered at home by next of kin, in the healthcare facilities by professional nurses, at places of work by co-workers and managers, and in the society by elders. Nkani and Bhana (2016) speak of support by family and support by close relatives to emphasize that family or parental support enables parenting students to return to school and be successful in their schooling. Haufiku (2014) maintains that parenting students need support with babysitting as insufficient support from relatives, friends and the school setting results in high dropout rate amongst expectant students.

Brosh, Weigel and Evans (2009) recognize the necessity for close relatives, friends, educators, professional nurses and social workers to give support to expectant students. They maintain that social support permits vulnerable students to realize their goals by empowering them to overcome barriers.

\subsection{Summary of the Definition of 'Social Support'}

Social support refers to encouraging, helping as well as the encouragement and help offered and communicated to individuals in challenging situations by a network of other people they are living with so that they gain competence to succeed in achieving their goals.

\subsection{Synthesized Definition of 'Facilitation of Social Support'}

Facilitation of social support is a method of making it easy for an expectant student to be given empowering and 
enabling help, offered and communicated by a network of educators, close relatives, and professional nurses to encourage and increase her competence to overcome challenges of receiving healthcare and education.

\section{Construction of a Model Case}

Walker and Avant (2011) refer to a model case as an illustration showing the use of a concept with all its defining attributes. Chinn and Kramer (2011) explain a model case as an accurate illustration of a condition, incident or experience to the best of an individual's present comprehension. It can be a real-life example, an example from healthcare setting, writings, paintings, movies, or it can be a researcher's conception (Chinn \& Kramer 2011; Walker \& Avant 2011). Below is a model case showing defining attributes of facilitation of social support aimed at expectant students in South Africa.

Sedile (fictitious name) is a 17 -year-old Grade 11 student who is expectant. She consulted at a mobile clinic that goes to her school three times a month. After doing a pregnancy test, the professional nurse started a relationship with Sedile to support her with information about pregnancy and presented her with available choices of action. Sedile got confused when learning of her pregnancy and felt that she had disappointed her close relatives and educators. She felt worthless and ashamed of being expectant while still attending school and thought of dropping out. The professional nurse encouraged and helped Sedile to tell her mother she was expectant and planned to visit Sedile's family to deliberate on the necessary support to succeed as an expectant student. As such, Sedile felt empowered and able to tell her mother she was expectant. The professional nurse also made it easy for Sedile's mother to talk with the school principal about Sedile's pregnancy. The school principal discussed Sedile's pregnancy with other educators. The school principal and the professional nurse discussed how other educators can support Sedile to remain in school and attend ANC. The professional nurse facilitated a meeting of the school principal and Sedile's mother to talk about their social support to Sedile such that she can manage school tasks and go to ANC regularly. The school principal told Sedile to remain in school. Her educators were told about her pregnancy and would support her to be successful. This support paved the way for Sedile to show the school principal a timetable of her ANC appointments and found it easy to request leave of absence. When coming back to class, educators gave her information on the classes she could not attend, and some fellow students helped her too. The professional nurse went to the school on a regular basis to support Sedile and reminded her that she was part of a network of concerned and accessible people to support her in order to achieve her goal, and as such, her anxiety of being an expectant student was reduced. At first, her close relatives were saddened and annoyed with her pregnancy but at the end they had accepted and were supportive. They purchased new school uniform and shoes for her, and showed interest in her schooling and ANC attendance. They prepared for the baby's arrival and told Sedile they would support her with babysitting so she could concentrate on school tasks. The professional nurse gave health education to students regularly on pregnancy during which they were encouraged to support expectant students and to stop bringing up undesirable things that could cause distress. Due to social support, Sedile grew in competence to be successful in her goals.

The model case shows the attributes, antecedents and consequences of facilitation of social support to an expectant student by a professional nurse.

\section{Antecedents and Consequences of 'Facilitation of Social Support'}

Walker and Avant (2011) describe antecedents as actions that must take place before a concept, while consequences occur as result of a concept. Antecedent concepts refer to conditions that come before facilitation of social support occurs. These concepts have a causal relationship with the facilitation of social support. For facilitation of social support aimed at expectant students to occur, there should be an expectant student, a school, home, primary health care (PHC) clinic and a competent facilitator.

Concepts that follow after facilitation of social support has happened are known as consequent concepts. A causal connection exists between them. The consequent concepts for facilitation of social support are improved self-esteem leading to ANC attendance. Professional nurses, who communicate with expectant students, their close relatives and educators, give personalized nursing care to ensure expectant students are retained in school and then give birth to healthy babies.

\section{Conclusion}

Facilitation of social support is important to enable expectant students to receive coordinated and empowering social support. It leads to improved feelings of competence to overcome challenges to attain education and attend ANC. Implementation of facilitation of social support may results in regular ANC attendance during which personalized nursing care is given by professional nurses who communicate with expectant students, their close relatives and educators to ensure expectant students are retained in school and at the end give birth to healthy 
babies.

\section{Acknowledgements}

The financial assistance of the National Research Foundation (NRF) towards this research is hereby acknowledged. Opinions expressed and conclusions arrived at, are those of the author and are not necessarily to be attributed to the NRF.

\section{Competing Interests Statement}

The author declares that there are no competing or potential conflicts of interest.

\section{References}

Baloyi, M. E. (2016). The "vat-en-sit" unions as a threat to the stability of African marriage in South Africa: African theological pastoral perspective. Phronimon, 17(2), 1-16. http://dx.doi.org/10.17159/2413-3086/2016/1955

Baxter, C., \& Moodley, D. (2015). Improving adolescent maternal health. South African Medical Journal, 105(15), 948-951. 10.7196/SAMJ.2015.v105i11.10126.

Bhana, D., \& Mcambi, S. J. (2013). When schoolgirls become mothers: Reflections from a selected group of teenage girls in Durban. Perspectives in Education, 31(1), 11-19.

Brosh, J. Weigel, D., \& Evans, W. (2009). Assessing the supports needed to help expectant and parenting teens reach their educational and career goals. Journal of Extensions, 47(1), 1-7.

Chinn, P. L., \& Kramer, M. K. (2011). Integrated theory and knowledge development in nursing (8th ed.). ST. Louis: Elsevier Mosby.

Collins Dictionary of English. (2011). (11th ed.). Glasgow: HarperCollins Publishers.

Collins English Thesaurus. (2013). (5th ed.). Glasgow: HarperCollins Publishers.

Duman, N. B., \& Kocak, C. (2013). The effect of social support on state anxiety levels during pregnancy. Social Behavior and Personality, 41(7), 1153-1164. http://dx.doi.org/10.2224/sbp.2013.41.7.1153

Haufiku, A. N. (2014). Teachers' Experiences and practices of support for school-going teenage mothers in Namibia. (Unpublished masters dissertation). University of Stellenbosch, Stellenbosch

Heaney, C. A., \& Israel, B. A. (2008). Social networks and social support. In Glanz, K. Rimer. B. K. \& Viswanath, K. (eds). Health behaviour and Health Education: Theory, Research and Practice, (pp 189-210). San Francisco: John Wiley and Sons.

Hrbackova, K., \& Suchankova, E. (2016). Self-determination approach to understanding of motivation in students of helping professions. Procedia-Social and Behavioral Sciences, 217, 688-696, https://doi.org/10.1016/j.sbspro.2016.02.120

Kanku, T., \& Mash, R. (2010). Attitudes, perceptions and understanding amongst teenagers regarding teenage pregnancy, sexuality and contraception in Taung. South African Family Practice, 52(6), 563-572. https://doi.org/10.1080/20786204.2010.10874048

Kheswa, J. G. (2017). Exploring the factors and effects of non-adherence to antiretroviral treatment by people living with HIV/AIDS. Indo-Pacific Journal of Phenomenology, 17(1), 1-11. https://dx.doi.org/10.1080/20797222.2017.1280923

Kheswa, J. G., \& Hoho, V. N. (2017). Exploring the factors and effects of alcohol abuse on the behaviour of university female students at one South African University Campus. Rupkatha Journal on Interdisciplinary Studies in Humanities, 9(1), 291-300. https://dx.doi.org/10.21659/rupkatha.v9n1.29

Kim, T. H. M., Connolly, J. A., \& Tamim, H. (2014). The effect of social support around pregnancy on postpartum depression among Canadian teen mothers and adult mothers in the maternity experiences survey. BMC Pregnancy and Childbirth, 14, 162. https://doi.org/10.1186/1471-2393-14-162

Kwatubana, S., \& Mtimkulu, M. N. (2017). Exploring Black Student Teachers Motivation for Community Service Involvement. Rupkatha Journal on Interdisciplinary Studies in Humanities, 9(1), 280-290. https://dx.doi.org/10.21659/rupkatha.v9n1.28

Lin, F.-Y., Rong, J.-R., \& Lee, T.-Y. (2013). Resilience among caregivers of children with chronic conditions: A concept analysis. Journal of Multidisciplinary Healthcare, 6, 323-333. http://doi.org/10.2147/JMDH.S46830 
Maharlouei, N. (2016). The importance of social support during pregnancy. Women's Health Bulletin, $3(1)$, e34991. https://dx.doi.org/10.17795/whb-34991.

Manikkam, L., \& Burns, J.K. (2012). Antenatal depression and its risk factors: An urban prevalence study in KwaZulu-Natal. South African Medical Journal, 102(12), 940-944. https://dx.doi.org/10.7196/SAMJ.6009

Masala-Chokwe, M. E., \& Ramukumba, T. S. (2017). The lived experiences and social support needs of first-time mothers at health care facilities in the City of Tshwane, South Africa. Curationis, 40(1), 1-8. http://dx.doi.org/10.4102/curationis.v40i1.1680

Matlala, S. F. (2016). A model for the facilitation of health for pregnant learners attending secondary schools in Limpopo province (Unpublished doctoral dissertation). University of South Africa, Pretoria.

Matlala, S. F. (2015). "It is not good for a pregnant person and it has never been and it will never be": Experiences of parents whose daughters became pregnant while attending secondary schools in Limpopo Province, South Africa. African Journal for Physical, Health Education, Recreation and Dance, Supplement 1, 1 (October), 22-36.

Matlala, S. F., Nolte, A. G. W., \& Temane, M. A. (2014). The need for a model to facilitate health for pregnant learners attending secondary school in South Africa. Mediterranean Journal of Social Sciences, 5(25), 83-91. https://dx.doi.org/10.5901/mjss.2014.v5n25p83

Mattson, M., \& Hall, J. G. (2011). Health as communication nexus: a service-learning approach (1st ed.). Dubuque; IA: Kendall Hunt Publishing.

Miriri, T. M., Ramathuba, D. U., \& Mangena-Netshikweta, M. L. (2014). Social factors contributing to teenage pregnancy in Makhado Municipality, Limpopo province, South Africa. African Journal for Physical, Health Education, Recreation and Dance, (Supplement 1:1), 130-141.

Mnguni, I. B. (2014). Investigating the causes of student dropout at secondary schools in Johannesburg South, Gauteng. (Unpublished masters dissertation). University of South Africa, Pretoria.

Moletsane, R. (2011). The need for quality sexual and reproductive health education to address barriers to girls' educational outcomes in South Africa. Working papers from the 2014 ECHIDNA global scholars. The Center for Universal Education at the Brookings Institution

Mona, T. P. (2014). A narrative analysis of the experiences of women on antiretroviral therapy in the Mopani District of Limpopo Province: Comparing private and public institutions in South Africa. In D. D Oliveiri, \& K. Leurs, (Eds.), Everyday feminist research praxis: Doing gender in the Netherlands (pp 168-186). Tyne: Cambridge Scholars Publishing.

Motjelebe, N. J. (2009). The social support network of teenage mothers in Botshabelo (Unpublished masters dissertation). University of Stellenbosch, Stellenbosch.

Moxley, D., \& Feen, H. (2017). Organizing for Arts-Based Social Action in the Helping Professions. Journal of Cultural Research in Art Education, 34, 116-133.

Mutshaeni, N. H., Malovhele, P. T., Lebese, R. T., \& Mashau, S. (2015). Barriers Faced by Pregnant Students When Trying to Finish Their Education in Vhembe District of Limpopo Province, South Africa. International Journal of Educational Sciences, 8(2), 327-332. https://doi.org/10.1080/09751122.2015.11890255

Nkani, N., \& Bhana, D. (2016). Sexual and reproductive well-being of teenage mothers in a South African township school. South African Journal of Education, 36(2), 1-10. http://dx.doi.org/10.15700/saje.v36n2a1181

Oxford Advanced Learner's Dictionary. (2010). (2nd ed.). Oxford: Clarendon Press.

Oxford Dictionary of English. (2006). (2nd ed.) revised. New York: Oxford University Press.

Oxford Dictionary of Nursing. (2008). (5th ed.). Oxford: Oxford University Press.

Oxford South African Concise Dictionary. (2006). (2nd ed.). Cape Town: Oxford University Press Southern Africa.

Parker, L. (2011). An ecological perspective of adolescents' need for support during pregnancy. (Unpublished masters dissertation). University of Stellenbosch, Stellenbosch

Petrova, M. Dale, J. Munday, D. Koisten, J. Agarwal, S. \& Lall, R. (2010). The role and impact of facilitators in primary care: findings from the implementation of the Gold Standards Framework for palliative care. Family 
Practice, 27, 38-47. https://doi.org/10.1093/fampra/cmp066

Roos, A. Faure, S., Lochner, C., Vythilingum, B., \& Stein, D. J. (2013). Predictors of distress and anxiety during pregnancy. African Journal of Psychiatry, 16, 118-122. http://dx.doi.org/10.4314/ajpsy.v16i2.15.

Rycroft-Malone, J., Seers, K., Chandler, J., Hawkes, C. A., Grichton, N., Allen, C., ... Strunin, L. (2013). The role of evidence, context, and facilitation in an implementation trial: implications for the development of PARHIS framework. Implementation Science, 8(28). https://doi.org/10.1186/1748-5908-8-28

Schenck, R., \& Louw, H. (2008). Conceptual research on the term facilitation: reducing an elephant to chewable chunks. Social Work/Maatskaplike Werk, [S.1.], 44(4), 369-380. http://dx.doi.org/10.15270/44-4-229.

Shefer, T., Bhana, D., \& Morrel, R. (2013). Teenage pregnancy and parenting at school in contemporary South African contexts: Deconstructing school narratives and understanding policy implementation. Perspectives in Education, 31(1), 1-10.

Skobi, F., \& Makofane, M. (2017). Reflections of social workers on the experiences of pregnant teenagers during group work sessions. Social Work/Maatskaplike Werk, 53(2), 224-249. https://dx.doi.org/10.15270/52-2-566

Streubert, H. J., \& Carpenter, D. R. (2011). Qualitative research in nursing: Advancing the humanistic imperative (5th ed.). Tokyo: Lippincott Williams \& Wilkins.

Škvorc, L., \& Bjelajac, A. K. (2016). Sleep Beliefs and Circadian Typology of Helping Professions Students. $\begin{array}{lllll}\text { International Online Journal of Educational Sciences, } & \text { 8(5), }\end{array}$ http://dx.doi.org/10.15345/iojes.2016.05.008

Van Zyl, L., Van Der Merwe, M., \& Chigeza, S. (2015). Adolescents' lived experiences of their pregnancy and parenting in semi-rural community in the Western Cape. Social Work/Maatskaplike Werk, 51(2), 150-173. http://dx.doi.org/10.15270/51-2-439

Walker, L. O., \& Avant, K. C. (2011). Strategies for theory construction in nursing (5th ed.). Sydney: Prentice Hall.

Williams, M. (2016). Police social work in South Africa. Social Work/Maatskaplike Werk, 52(1), 129-143. http://dx.doi.org/10.15270/52-1-483

Yeboah, M. K. (2012). Social support and access to prenatal health services: a study of pregnant teenagers in Cape coast, Ghana. Journal of Science and Technology, 32(1), 68-78. http://dx.doi.org/10.4314/just.v32i1.8

\section{Copyrights}

Copyright for this article is retained by the author(s), with first publication rights granted to the journal.

This is an open-access article distributed under the terms and conditions of the Creative Commons Attribution license (http://creativecommons.org/licenses/by/4.0/). 